\title{
III SPOTKANIE EKSPERTÓW \\ FIZJOTERAPIA-ORTOPEDIA-REUMATOLOGIA-KARDIOLOGIA
}

13 grudnia 2019, godz. 11:00-17:00

SALA SENATU Uniwersytetu Medycznego w Poznaniu przy ul. Przybyszewskiego 37a

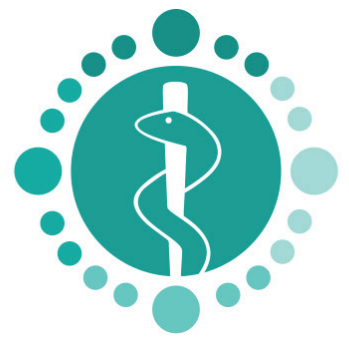

\section{Spotkanie Ekspertów \\ spotkanieekspertow.pl}

Patronat Honorowy

Marszałek Województwa Wielkopolskiego Pan Marek Woźniak

Prezydent Miasta Poznania Pan Jacek Jaśkowiak

JM Rektor Uniwersytetu Medycznego w Poznaniu Prof. Andrzej Tykarski

\section{Ramowy program}

1. Interdyscyplinarne leczenie dysfunkcji kończyny górnej

2. Dokumentacja medyczna

3. Współpraca Lekarza z Fizjoterapeutą dotycząca pacjenta „kardiologicznego”

Spotkania Ekspertów dają możliwość skonfrontowania różnych idei, swobodnej wymiany poglądów i doświadczeń, wypracowania nowych rozwiązań. Co roku zapraszamy wybitnych praktyków z całej Polski oraz wybranych gości z innych krajów. Koncepcje i metody leczenia zmieniają się na przestrzeni lat wraz z rozwojem fizjoterapii, procedur operacyjnych, środków farmakologicznych czy dostępnego sprzętu. Dlatego też, zaprosiliśmy na nasze zamknięte, kameralne spotkanie Panią / Pana oraz innych uczestników, którzy bazując na zdobytej wiedzy i wieloletnim doświadczeniu, podejmą próbę wypracowania najlepszego- skutecznego multidyscyplinarnego podejścia do omawianych problemów klinicznych. Głęboko wierzymy, że podczas naszego forum wybitnych specjalistów każdy z zaproszonych gości przedstawi swój podgląd i podejmie dyskusję.

W tym roku jak i poprzednim umożliwiamy wzięcie udziału w spotkaniu 30 słuchaczom, którzy zasiądą pośród wybitnych specjalistów i będą mogli wziąć udział w interdyscylinarncyh dyskusjach. Informacje o zapisach na www.SpotkanieEkspertow.pl

\section{Z poważaniem,}

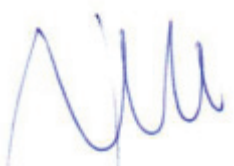

Prof. dr hab. W. Samborski Przewodniczący Komitetu Naukowego

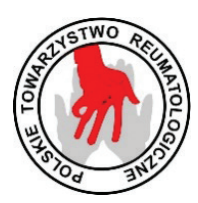

Z poważaniem

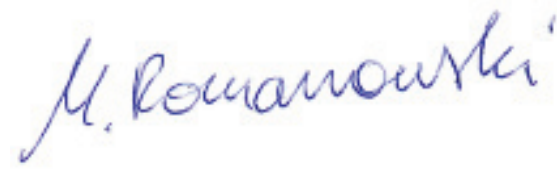

dr M.W. Romanowski

Przewodniczący Komitetu Organizacyjnego
Krajowa Izba Fizjoterapeutów
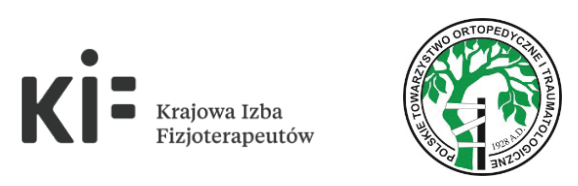
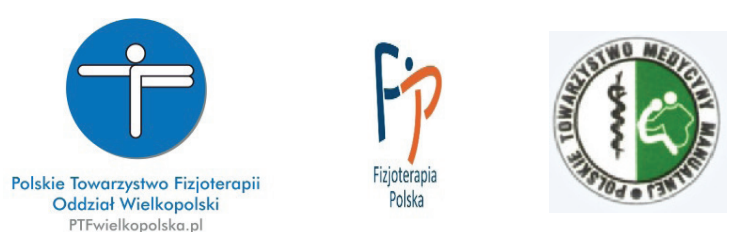